\title{
COMMUNITY EMPOWERMENT THROUGH NON FORMAL EDUCATION
}

\section{Muhammad Fahmi}

Green Publisher

Email: fahmimuhammad103@gmail.com

Keywords
Covid-19
pandemic,
Empowerment
,non-formal
education

Article Info Accepted: July, $2^{\text {nd }} 2019$ Revised: July, $9^{\text {th }} 2019$ Approved: July, $10^{\text {th }} 2019$

\begin{abstract}
Empowerment means encouragement or motivation, guidance, or assistance in increasing the ability of individuals or communities to be able to be independent. This effort is a stage of the empowerment process in changing behavior, changing old habits to new good behaviors. In the Pandemic era like the one that hit today, the condition of formal education activities was really empty. Conditions and government policies that force people to limit activities including formal education. In the era of the Covid 19 Pandemic, implementing or organizing education is something that is difficult to do. The government policy regarding the existence of restrictions on activities (social distancing) resulted in a freeze in the activities of the formal education world. In this context, the importance of non-formal education is to meet the educational needs of children in the community. The existence of non-formal education will greatly help the community in terms of limited activities in social life. Cempaka Village has non-formal education activities which are engaged in the education of reading and writing al-Qur'an starting from Juz Ammah to being proficient in reading al-Qur'an. This non-formal education accepts students from the age of 6 to 17 years.
\end{abstract}

\section{Introduction}

This brief study seeks to raise the topic of community empowerment in outof-school education or formal educational institutions, which contains how society deals with learning problems for children in the Covid-19 Pandemic era (Rusmiyati, 2020). This is done to explain the condition of society and as an effort to improve the community's ability to be able to solve the problems it is experiencing or what is known as civil society. A 


\section{Muhammad Fahmi}

society that believes in the ability of its members to create a better life and a society that is aware of their rights and obligations in social life (Fitriana \& Elshap, 2015). Where the conditions for empowerment will be realized if members of the community have the opportunity to improve their ability to face problems so that they are more empowered. In achieving thiscondition, it is necessary to have external parties, in this case, non-formal education officers to help see the potential or abilities of the community sothat they can empower themselves (Karim, 2017)

The pandemic problem does not only affect the economic problems of the community, but all lines of community life are disrupted by the pandemic problem (BAKRI, 2020). Apart from having an impact on economic problems, the socio-religious side also experienced disturbances. It is undeniable that this pandemic outbreak has attacked all lines of community life (SOLIKHAH, 2021). The limitations of society in social interaction, for example, will interfere with aspects of community religious life (Amran, 2015) Such as in matters of worship and routine community activities in terms of religious ritual activities.

The Covid 19 pandemic has changed the life order of the world community in a very short time (Habibi, 2020)In the context of societal change, the impact of the Covid 19 Pandemic has made people's lives change in terms of 180 degrees of social interaction patterns. Of course this impact sociologically causes unplanned changes. In other words, social change that occurs sporadically and uncontrollably has a very negative impact (Jamaludin, 2015). As a result, the people's unpreparedness in facing this pandemic has in turn led to social disorganization in all aspects of people's lives.

Another impact of the Covid 19 Pandemic was a negative impact on social values and norms adhered to by the community. Even so, basically society will always experience changes. Thus, all forms of community activities carried out in the pre-pandemic period must now be forced to comply with standard health protocols. Of course this is not a simple matter. Because the Covid-19 pandemic has infected all aspects of the order of people's lives that have been institutionalized through routine and repetitive patterns. In fact, the community will be faced with a situation of change that was never imagined before. A number of old values and norms must be restructured and reproduced again to produce a new social system. The emergence of the new regulations was marked by, among other things, an appeal from the government to study, work and worship at home since thebeginning of the emergence of this virus in Indonesia. Likewise with the customary pattern of people who are friendly, like to gather and shake 

hands, now they are required to get used to social restrictions. To reduce the burden of problems in society, it is appropriate to do various things to increase public optimism in the midst of this pandemic. Many people who are still able to meet their daily needs have increased their concern by contributing to helping the underprivileged by raising funds, including what is done by the academic world by carrying out community service through empowerment. Community empowerment in the fields of education, economy, social and other is a real effort that can be done by people who care about the social conditions of society today. What's interesting in this research is how to empower the community in the realm of Islamic education in an era of social change due to the impact of the Covid Pandemic 19.

\section{Method Research}

\section{Approach and Type of Research}

This research is a research that uses qualitative methods with the type of case study (case study). Researchers will use a sociological-hystical point of view. The aim is to explore and at the same time examine the social phenomena of the community concerning the issue of Community Empowerment through Non-Formal Education (Study of Islamic Education for Children in the Covid 19 Pandemic Era in Cempaka Plumbon Village Cirebon). Thus, this research is included in a case study of social phenomena.

\section{Research Data Sources}

Sources of data that will be used in this research are related data sources, both primary and secondary data. The primary data source is in the form of data and information obtained from the field. The data can be in the form of information from predetermined sources as well as documents thathave been successfully compiled from the field. Meanwhile, what is meant by secondary data are materials that can be viewed as data that are in accordance with related research, and therefore these materials must also be given the same treatment and management.

\section{Result and Discussion}

\section{Community Empowerment}

Conceptually, empowerment or empowerment (empowerment) comes from the word 'power' which means power or empowerment. Therefore, the main idea of empowerment is related to the concept of power. Power 
is often associated with our ability to make other people do what we want, regardless of their desires and interests (Nafisah, 2019). Empowerment as a change process then has a meaningful concept.

In relation to the concept of community empowerment, many experts discuss this. One of them is Payne, who argues that empowerment is primarily aimed at helping clients gain the power to make decisions and determine the actions they will take related to themselves, including reducing the effects of personal and social barriers in taking action. This is done through a confident phase to use the power he has, including through the transfer of power from his environment.

In its implementation, empowerment means encouragement or motivation, guidance, or assistance in increasing the ability of individuals orcommunities to be able to be independent. This effort is a stage of the empowerment process in changing behavior, changing old habits to new good behavior, in improving the quality of life and welfare, as well as creative and comprehensive critical thinking, so that from the results of this empowerment the community is able to increase the level of surveyinggood in all conditions due to change.

From these various views, it is clear that the concept of community empowerment must be based on the involvement of all parties, both government and all levels of society. Therefore, the formulation is taken that the concept of community empowerment is a development design through a process of developing and exploiting potential resources that involves all parties, both the community and the government, to realize thewelfare of people's lives in various fields.

Thus, the targets and objectives themselves can differ according to the development sector being worked on. The goal of empowerment in the economic sector is not necessarily the same as the goal of empowerment in the education or social sector. For example, the objective of economic empowerment is for the target group to manage their business, then market and form a relatively stable marketing cycle. In the field of education, it has a goal so that the target group can explore the various potentials that exist within themselves and utilize their potential to overcome the problems they face. Meanwhile, the goal of empowerment in the social sector, for example, is so that the target group can carry out itssocial functions again with social roles and tasks.

Empowerment is closely related to development, where development is essentially a series of efforts carried out continuously to achieve a

Community Empowerment Through Non Formal 
prosperous community life both physically and mentally, for this reason community participation in development is needed because they are the object as well as the subject of development, so that a participatory development model develops. Participatory development is a development approach that is in accordance with regional autonomy which attaches the foundation of development that grows from the community, is carried out consciously and independently by the community and the results are enjoyed by the whole community (Janice, 2014). Thus, the main objective of empowerment is to strengthen the power of society, especially the weak groups who do not have empowerment, either because of internal conditions or because of external conditions (there is injustice in the social structure).

\section{Non Formal Education}

According to the type, education can be divided into three types, which include formal education, non-formal education and informal education. This difference does not only lie in differences in terms, but has differences in services, systems, content, content and those that are applied in their implementation. In addition, these types of differences also have implications for the policies applicable to each type of education. If formal education has tiered stages and legally it can be accepted by the government, however, non-formal education is sometimes not tiered and outside the formal legality of the government. Even so, in formal education there are also those who are tiered and have formal legality.

The most striking thing about the latter type of education is Informal Education. This third type has no level and even formal legality but is recognized by law and has its own role. Informal education is part of National education, which supports the achievement of its implementation goals. Therefore, these three types of education have their respective urgencies and roles in the National education system.

The character of non-normal education can be seen again as long as the programs implemented are always consistent with various processes that really pay attention to the community development program as a whole. People will choose programs that can really feel and make them feel recognized. Therefore, it is necessary that every non-formal education program development involves community participation as a whole and comprehensively. Not just a fleeting program. This is related to the formation of public trust in non-formal education programs (Jati, 2012).

Non-formal education is education that is carried out on a regular basis, 
consciously carried out, but not too strict following fixed rules, as in formal education in schools (Hidayat \& Machali, 2012). Because non-formal education is generally carried out not in a physical school environment, nonformal education is identified with out-of-school education. Therefore nonformal education is carried out outside of school, so the main target is community members. Therefore, non-formal education programs must be made in such a way as to be flexible but straightforward, but still attract the interest of education consumers.

Based on the results of research in the field, that non-formal education is really needed by members of the community who have not had the opportunity to attend formal education. Especially in the Pandemic era like the one that hit today, the condition of formal education activities was really empty. This means that all formal education is carried out in their respective homes. Conditions and government policies that force people to limit activities including formal education. Policies such as Social Distancing, PSBB (Large-Scale Social Restrictions) that occurred during 2020, starting from the beginning of the year until today have resulted in paralysis in various sectors of community life, including educational institutions.

Therefore, alternatives are needed from the impact of the Covid 19 Pandemic. A possible alternative in the education sector is the holding of out-of-school education (Non-Formal-Informal Education) (Sudarsana, 2016). However, seeing the effectiveness in the educational process when compared between non-formal and informal education, according to the researchers, non-formal education has a level of effectiveness in learning, including in replacing the need for formal education for children in the community. Because basically non-formal education is organized by an educator, at least having qualified experience and knowledge. Although in terms of professionalism it is doubtful because they do not have a Bachelor's educational background for administrative staff. Then besides that, the benefits of non-formal education can also facilitate children in assisting school assignments while schools are closed due to the impact of the Covid 19 pandemic.

In the end, the most important goal of non-formal education is the programs or even the conditions of problems that occur in society (Miradj \& Sumarno, 2014). therefore non-formal education must be in line and integrated with the development programs needed by the community. To bridge this gap, the role of non-formal and informal education (PNFI) is very important, it has even become alternative education for people in the era of

the Covid Pandemic 19.

Community Empowerment Through Non Formal 


\section{Empowerment Approach}

One of the most important things in this research is the approach used by community groups in the empowerment approach through non-formal education. This means that it concerns policies that can be used as guidelines in the implementation of empowerment as a whole, comprehensively and thoroughly. So that the goals, targets and objectives to be achieved in community empowerment through this non-formal education can be maximally achieved. Especially in the conditions of the Covid-19 Pandemic, many problems were faced. Of course, seeing these conditions requires appropriate, accurate, measurable and effective policies so as to produce an optimal final result.

\section{The Concept of Empowering Non-Formal Education in the Covid Era 19}

At this time, education is a very important need. The importance of education in the Islamic viewpoint even explains that education for humans is carried out for life. In the era of the Covid-19 Pandemic, implementing or organizing education is something that is difficult to do (Leoni, 2021). The government policy regarding the existence of restrictions on activities (social distancing) resulted in a freeze in the activities of the formal education world. In this context, the importance of non-formal and informal education to meet the educational needs of children in the community. The existence of non-formal education willgreatly help the community in terms of limited activities in social life.

Cempaka Village is one of the villages in the Plumbon District of Cirebon Regency. Cempaka Village has non-formal education activities which are engaged in the education of reading and writing al-Qur'an starting from Juz Ammah to being proficient in reading al-Qur'an. This non-formal education accepts students from the age of 6 to 17 years. They are required to study the Koran because according to society, the Koran teacher and their parents if they want to continue their education to junior high school the requirement is to be proficient in reading the Koran. Not only does it equip students to learn to read but the ability to write is taught, even religious teachers teach reading the yellow book.

In conditions outside the Pandemic, this non-formal education activity has a fairly busy schedule. Writing and reading al-Qur'an activities are carried out every day twice a day between 14.30 and bad'da magrib. After the Pandemic period, activities in non-formal education were only carried out once, namely ba'da manggrib until 20.00 WIB. The high enthusiasm and interest in the chanting of the children did not escape the encouragement 
and direction of their parents and also the children were not disturbed by their learning activities at school because they were carried out in a nonformal environment or in the community. Although sometimes the children look tired but all of that is lost because seeing their friends join the Koran together, apart from the Koran, they can also meet and play with their peers.

In general, teaching children to read the Qur'an has a different experience from teaching adults. Generally, it is difficult to teach children because there are those who are quick to understand the recitation of the al- Qur'an, some are slow to understand recitation of the al-Qur'an. Because basically, the childishness of the age described above still tends to be high. The desire to joke, play with friends and so on is still high. Even so, the experience of teaching the Qur'an to children has a good impression. And starting with children's motivation to play and meet their playmates, that motivation can be directed to positive activities such as reciting and writingthe Qur'an. The Koran teachers in Cempaka Village have a strategy on how to succeed in nonformal education, in teaching reading and writing the Qur'an. One of them is a strategy in dealing with the problem of children who are slow to follow learning materials, this is done by using a special approach and given a special education so that children are not insecure when they see their friends who are already proficient in reading the Koran. .

Parents play an important role in the success and development of children while the duties and responsibilities for this are joint duties between parents, society, and the child itself, naturally the child is born and raised in the family, since birth the child has been influenced by the environment closest namely family. Education that is received before entering formal education is non-formal education that comes from the family and community, this is where the character and personality formation of children begins, but not all environments support children's education, there are environments that have a negative influence on children that interfere with the child's learning process.

For the teaching staff in Cempaka-Plumbon Village, understanding education in the community does not only function as an inculcation of attitudes but how we are taught their values and norms are also taught how to be polite to others, be disciplined and also responsible and also have good morals especially teenagers in Cempaka-Plumbon Village. Then its application in people's lives so that they understand what should be done and what should not be done and respect people who are older than us and also as a substitute for formal education, both for students who 
have faith in God Almighty, prospering themselves and their families. Education is a primary and primary need for children, especially reading the al-Qur'an. Moreover, talking about monotheistic education that must be taught and instilled in children from an early age to adulthood. In this context, support is needed from the child's closest factor, namely family. Family is a factor that influences children's behavior, it is not surprising that our values, self-concept or personal are influenced by our families and associations, family is responsible for the socialization process in the transmission of cultural values and community values. There are two factors that influence adolescent social behavior, namely internal factors and external factors. 1). Internal factors are factors that come from within humans themselves, these factors can be in the form of instincts, inner motives, attitudes and passions. 2). External factors External factors are factors that come from outside humans who are influenced and can be seen from the environment a person lives in.

The Relationship between Research Results and Theory Such as the Behavioristic theory of social behavior. This theory focuses its attention on the relationship between the consequences of behavior that occurs in the community. Where adolescent behavior is a factor that needs to be handled so as not to disturb the community. Behavioral theory in sociology seeks to explain the historical relationship between the effects of past behavior that occurs in the environment, the actor and the current behavior of the actor. That is, the theory explains that behavior that occurs in the present is the result of behavior that occurred in the previous period.

\section{Conclusion}

Non-Formal Education is an alternative education in the Pandemic Era. Amid limited conditions, the needs of the community must be served and fulfilled. It is not only the problem of economic needs that must be fulfilled in the Pandemic era, but all aspects including education for the community must be fulfilled. 2020 is a very bad year for the Indonesian people, for onefull year, Covid 19 has plagued this nation.

The impact that occurs as a result of this outbreak is of course fatal to the process of implementing education for the community. But for the people of Cempaka Kec. Plumbon, Kab. Cirebon is still well served in education. With the existence of non-formal education which is carried out regularlyby the community, the needs of children's education problems have been fulfilled. Even the existence of non-formal education in Cempaka Village is an alternative education, which can be an answer to educational problems in the community. As a result of the government's PSBB policy, of course 
schools are closed, but non-formal education can provide assistance to children in matters of educational needs, such as in carrying out school assignments that are given because the school is closed.

\section{References}

Amran, Ali. (2015). Peranan Agama Dalam Perubahan Sosial Masyarakat. Hikmah: Jurnal IImu Dakwah Dan Komunikasi Islam, 2(1), 23-39.

Bakri, Wahyuddin. (2020). Bunga Rampai Pandemi.

Fitriana, Wedi, \& Elshap, Dewi Safitri. (2015). Revitalisasi Peran Pendidikan Luar Sekolah Dalam Pemberdayaan Masyarakat. Empowerment: Jurnal IImiah Program Studi Pendidikan Luar Sekolah, 4(1), 58-66.

Habibi, Andrian. (2020). Normal Baru Pasca Covid-19. Adalah, 4(1).

Hidayat, Ara, \& Machali, Imam. (2012). Pengelolaan Pendidikan: Konsep, Prinsip, Dan Aplikasi Dalam Mengelola Sekolah Dan Madrasah. Kaukaba.

Jamaludin, Adon Nasrullah. (2015). Sosiologi Perkotaan: Memahami Masyarakat Kota Dan Problematikanya. Pustaka Setia.

Janice, Astrella. (2014). Studi Tentang Pelaksanaan Tugas Dan Fungsi Badan Pemberdayaan Masyarakat Desa (Bpmd) Dalam Pembangunan Desa Di Desa Tanjung Lapang Kecamatan Malinau Barat Kabupaten Malinau. Jurnal Ilmu Pemerintahan.

Jati, Widi Sasmito. (2012). Kajian Kegiatan Penyuluhan Melalui Pendekatan Pengelolaan Tanaman Terpadu (Ptt) Padi Sawah Di Bpp "Tani Budaya" Kecamatan Mojolaban, Kabupaten Sukoharjo.

Karim, Abdul. (2017). Efektivitas Partisipasi Perempuan Pada Pendidikan Non Formal Di Pusat Kegiatan Belajar Masyarakat (Pkbm) Kecamatan Wedarijaksa Kabupaten Pati. Inferensi: Jurnal Penelitian Sosial Keagamaan, 11(1), 119-140.

Leoni, Tessa Dwi. (2021). Pembelajaran Apresiasi Sastra Sebagai Pendekatan Untuk Penguatan Karakter Dan Mental Anak Dalam Menghadapi Situasi Covid-19. Bahasa, Sastra, Dan Pembelajarannya Dalam Masa Pandemi Covid-19, 83.

Miradj, Safri, \& Sumarno, Sumarno. (2014). Pemberdayaan Masyarakat Miskin, Melalui Proses Pendidikan Nonformal, Upaya Meningkatkan Kesejahteraan Sosial Di Kabupaten Halmahera Barat. Jppm (Jurnal Pendidikan Dan Pemberdayaan Masyarakat), 1(1), 101-112.

Nafisah, Haifa Zainatun. (2019). Pemberdayaan Sumber Daya Manusia Pertanian Melalui Pelatihan Berwawasan Agribisnis: Studi Deskriptif Di Pusat Pelatihan Pertanian Dan Pedesaan Swadaya P4s Terpadu Ikamaja Desa Wanajaya Kecamatan Wanaraja Kabupaten Garut. Uin Sunan Gunung Djati Bandung. 
Rusmiyati, Siti. (2020). Manajemen Pendidikan Karakter Pada Masa Pandemi Covid-19 Di Sd Islam Al Furqon Rembang. Iain Kudus.

Solikhah, Tridiganita Intan. (2021). Dilema Pembelajaran Daring Selama Masa Pandemi Covid-19. Kampus Merdeka Seri 5: Transformasi Media Pengajaran Kampus Merdeka Di Era Kenormalan Baru, 75.

Sudarsana, I.Ketut. (2016). Pemikiran Tokoh Pendidikan Dalam Buku Lifelong Learning: Policies, Practices, And Programs (Perspektif Peningkatan Mutu Pendidikan Di Indonesia). Jurnal Penjaminan Mutu, 2(2), 44-53.

Copyright holder :

Muhammad Fahmi (2019)

First publication right :

Devotion - Journal of Community Service

This article is licensed under:

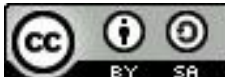

